\title{
Factors Affecting the Implementation of Low- Level Oral Questioning in Mathematics Teaching in Primary School
}

\author{
Muhammad Sofwan Mahmud, Aida Suraya Md. Yunus, Ahmad Fauzi Mohd Ayub, Tajularipin \\ Sulaiman
}

\begin{abstract}
The purpose of this study was to identify factors that influence the implementation of low-level oral questioning in mathematics teaching in primary school. This study was a qualitative study using the case study method. Data were collected through partial structural observation, semi-structured interview, document analysis and field notes. Six mathematics teachers from six different primary schools were selected as participants of the study using purposive sampling method. The data were then analyzed using a constant comparative method to identify the patterns and themes that emerged from the data obtained. The study identified that factors of time constraint, heavy workload, extensive coverage of contents, low level student achievement, student engagement, and lack of in-service training contributed to the lack of high level questionings in the mathematics teaching process. These factors need to be addressed so that students' thinking can be enhanced through higher level oral questioning activities during the class.
\end{abstract}

Keywords: Level of oral questioning, mathematics teaching, mathematics teachers, primary schools.

\section{INTRODUCTION}

In an effort to enhance students' thinking skills in mathematics learning, one of the techniques that can be used is to apply effective oral questioning techniques to students during the teaching process [1]. The use of oral questioning as a teaching strategy stimulates students' thinking and enables teachers to understand student achievement levels as well as providing opportunities for students to express their understanding [2]. In addition, teachers can also use oral questioning to challenge students' thinking, raising students' curiosity and interest in a given topic [3].

In this context, questioning techniques for effective teaching that should be used are high level questioning techniques in line with high level thinking skills which include application, analysis, evaluation and creation [4]. However, teachers need to vary the level of oral questioning in their teaching process to suit the circumstances and needs of students [5]. The ability of teachers to practice effective questioning skills and strategies has been an important element in their efforts to inculcate and apply thinking skills and is an art that teachers must master and practice [4]. However, in order to do this, a strong knowledge and skills structure on how to execute oral questioning at a higher

Revised Manuscript Received on September 14, 2019.

Muhammad Sofwan Mahmud, Faculty of Education, National University of Malaysia, Bangi, Selangor, Malaysia. (Email: sofwanmahmud@ukm.edu.my)

Aida Suraya Md. Yunus, Faculty of Educational Studies, Universit Putra Malaysia, Serdang, Selangor, Malaysia. (Email: aida@upm.edu.my)

Ahmad Fauzi Mohd Ayub, Faculty of Educational Studies, Universit Putra Malaysia, Serdang, Selangor, Malaysia. (Email: afmy@upm.edu.my)

Tajularipin Sulaiman, Faculty of Educational Studies, Universiti Putra Malaysia, Serdang, Selangor, Malaysia. (Email: tajulas@upm.edu.my) level plays a major role in ensuring that it is implemented accurately and effectively [6].

The use of high-level questioning techniques is seen as a more effective questioning technique [7]. In [8] emphasized that students need to apply their knowledge and understanding to get answers to questions posed by teachers. Using teachers' high-level questioning skills through problem-solving questions can open up the opportunity for more in-depth discussion, encourage exploration and enhance student engagement in the teaching process [9].

The use of effective oral questioning in the teaching of mathematics is very important to help students improve their thinking skills and to help students understand abstract mathematical concepts [6]. The use of higher level questions such as non-routine and divergent questions can help and train students to think at a higher level [8]. Questions like these enable students to better develop knowledge and help students to apply the existing knowledge they have in solving problems [1]. In this context, students' thinking should be stimulated by raising open-ended questions so that ideas or knowledge they have can be extended to help them understand new learning [10].

There are basically two levels of oral questioning, namely low-level and high-level oral questioning as found in the revised edition of Bloom's Taxonomy [11]. The lower levels of oral questioning include the level of knowing and understanding while the upper level questions include applying, analyzing, evaluating and creating. Each level of question used by a teacher has its own function and purpose and should be used according to the learning needs. The functions of each level of the question are shown as in Fig 1.

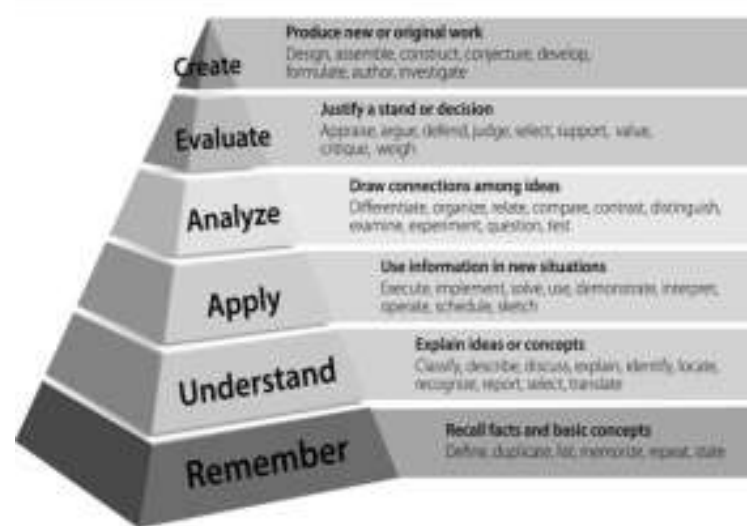

Fig. 1. Revised Bloom's Taxonomy Questions level 


\section{FACTORS AFFECTING THE IMPLEMENTATION OF LOW-LEVEL ORAL QUESTIONING IN MATHEMATICS TEACHING IN PRIMARY SCHOOL}

In addition, the use of appropriate level of oral questioning by teachers plays a significant role in enhancing students' thinking ability in mathematical learning [12]. However, previous studies showed that teachers prefer to ask lower-level questions rather than higher-level questions in their mathematics teaching process [7]. In addition, teachers are more likely to use only low or moderate level cognitive questions in their teaching activities and less focus on high-level cognitive questions [2]. Similarly, the findings of [13] found that most teachers more often use convergent type questions than divergent type questions in the mathematics teaching process. Consistent use of convergent questions will not improve student thinking [3].

In [14] states that low levels of thinking skills among students are due to the lack of effective oral questioning activities that stimulate students' thinking in the teaching of mathematics. The study of [15] found that teachers' questions in mathematics teaching revolve more about solution procedures and lesser on questions regarding conceptual understanding. In addition, he noted that questioning activities were not implemented in the mathematics teaching process whereby students were more exposed to questions related to tips or formulas that needed to be memorized for use in the calculation process especially in examination. However, based on the statement of problems discussed, so far very little is known about the extent that primary school mathematics teachers practice oral questioning in the teaching process. Therefore, this study was conducted to identify the factors that cause teachers to ask lower-level oral questions in the mathematics teaching process.

\section{METHODOLOGY}

This study was a qualitative study using the case study method. Six mathematics teachers from six different primary schools in a district in a state in Malaysia were selected as participants of the study using purposive sampling method. In this study, the researcher used the method of partial structural observation, semi-structured interview, document analysis and field notes. The use of various data collection techniques allow the researchers to triangulate the data at the data analysis level while also reinforcing the results obtained [16].

In this study, the analysis was conducted using the constant comparative analysis method to identify patterns and themes that emerged from the primary data gathered [17]. Constant comparison method involves combining data collection with analysis. Thus, the initial analysis of the data began as soon as the field work started. Thus, the process of data analysis and data collection was concurrent and

Teacher Yes. For a short period of time, we cannot afford high-level questions. Because when I go into class, I want students to gain the knowledge I pass on to them.

\footnotetext{
Researc You mean this high level question is not her appropriate in the short class period?

Teacher Yes, yes. This high level question will take a little longer for us to explain and for them to understand.
}

ongoing. The data collected in this study was analyzed using Atlas ti 8 software for themes and sub-themes.

In [18] stated that the validity and reliability of a study refers to the extent to which a study's findings can accurately and consistently represent the phenomenon understudied. Therefore, the researcher used several methods to enhance the validity and reliability of the study using triangulation method, member checking and peer review.

\section{RESULTS AND ANALYSIS}

The ages of the research participants ranged from 27 to 50 years old (Table I). Teachers Ana, Nadia and Ada who were in their twenties were selected to represent the novice teacher and all of them have less than four years of teaching experience. On the other hand, the novice teachers, Teacher Raha, Teacher Azah and Teacher Roza were more than 40 years of age and had more than 20 years of teaching experience. All the participants obtained undergraduate degrees in Math Education. Hence, the participants were considered to have the credibility, knowledge and skills to teach mathematics.

\section{Table- I: Educational background and teaching experience of the research participants}

\begin{tabular}{|c|c|c|c|c|c|c|}
\hline & Ana & Nadia & Ada & Raha & Azah & Roza \\
\hline Age & 28 & 27 & 28 & 46 & 50 & 44 \\
\hline $\begin{array}{c}\text { Mathematics } \\
\text { Teaching } \\
\text { Experience }\end{array}$ & 4 & 3 & 4 & 20 & 23 & 23 \\
\hline $\begin{array}{c}\text { Academic } \\
\text { Qualification }\end{array}$ & \multicolumn{6}{|c|}{ Bachelor Degree in Mathematics with Education } \\
\hline
\end{tabular}

The findings showed that the study participants have their own constraints in applying high-level oral questioning in mathematics teaching. As such, various reasons were given by each teacher as to why they were focusing more on lower level oral questions in the process of teaching mathematics.

The participants indicated that time constraint, heavy workload, extensive coverage of contents, low level student achievement, students' involvement, level of teachers' knowledge and lack of in-service training contributed to the lack of high level questionings in the mathematics teaching process.

\section{A. Time Constraint}

Time constraint was considered as the major obstacle in implementing high level questioning. This is based on the findings showing that all six participants expressed the opinion that time constraints made it difficult for them to perform high-level oral questioning in the mathematics teaching process. This was admitted by Teacher Raha who said that she prefers to use lower-level oral questions to help students understand and remember the contents of the lessons being presented. This is because high level oral questions require more time for students to complete. This was explained by her in the interview as explained in the excerpt below. 


\section{[Raha,II/18410-18764]}

In addition, Teacher Azah also stated that the time spent in teaching mathematics had to be used to complete various external tasks such as attending meetings because he was one of the administrators of her school.

"As one of the administrators of this school that deals with student affairs, my time with students to teach is limited as I am often out for meetings and other administrative matters. So when the time is up, I focus more on the level of knowing and understanding." [Azah,SRI2/17643-18421]

In addition, other teachers have said the same thing: "Not enough time to practice high level oral questions." [Ana,SRI1/12777-13211]", “... so busy, so that I do not have enough time to practice high-level questions during my teaching sessions..." [Ada,SRI2/19289-19401], “...very limited time to do high-level questions..."[Nadia,II/2126521230], "I need more time to plan and execute high-standard questions because time is too limited." [Roza,SRI3/2111721267]

\section{B. Heavy Workload}

Teacher Azah implied that the heavy workload does not give much time for her to focus on higher level oral questions during her teaching. This is shown in the interview excerpt below.

"Besides, I couldn't apply higher level questioning because of the rush of work outside. I always attend courses, workshops. Our time in the school is very short. So when I get into class I can't afford to go back to higher levels of questions. I mean, as long as students can master the basics for me, that's enough." [Azah,SRI 1/25536-25902]

However, the courses and workshops attended by Teacher Azah are not teaching-related courses but rather focus on the management and administration aspects of the school as Teacher Azah is a school administrator who manages student affairs [Azah, NL / 18102018]. In addition, it also lowers her perception of what students should achieve where he thinks it is sufficient for students to understand and remember the basics of a topic.

In addition, the various positions held by Teacher Ada at the school also contributed to the reason that high-level oral questions were not possible. In this context, Teacher Ada explained that she was assigned to a number of important positions in the school which led to her time with the students being less. These are shown as excerpts below.

"At school I hold a lot of positions, so I also feel a lot of workload which makes me unable to focus on high level oral questions because sometimes I have to focus more on the various tasks I need to complete.” [Ada,II/28054-28678]

\section{Extensive Coverage of Contents}

The syllabus for Year 5 Mathematics contains 18 topics. It is quite a rush for teachers to complete teaching all the topics. In addition, 'unfinished work' before entering a class may cause the teachers to feel less focused on the teaching and less time to prepare for high level oral questions. This is explained by Teacher Ana in the excerpt below.

"First, the math curriculum syllabus itself has 18 topics for this year. So that time limit means we have to waste time going to workshops, courses, meetings and so on. So, a teacher like me is in the classroom with the burden of an outside assignment never ending. I was already in the classroom and teaching. So, these students can sometimes be called victims. Of course I was looking to finish teaching quickly because there were so many syllables but time was not enough. That's why I couldn't ask the higher level questions because I was really pursuing time." [Ana,SRI 1/27874-28584]

Another teacher, Teacher Azah, also expressed the same opinion that the current mathematical syllabus is too much for teachers to complete in one school year. Teacher Azah also expressed her guilt feelings to move on to another topic if her students have not mastered the current topic. To provide enough time for her students to acquire the content, she finds that she can't spare the time to include high-level oral questions during the teaching. This is explained by Teacher Azah herself in the interview excerpt below.

"Indeed. The reason is that too many syllables are worth pursuing. Once a student has mastered one topic, then we have to move on to another. But it's hard for us to handle it all. Let's say there are 18 topics and at first the students don't understand; we feel guilty if we don't finish. We want to make sure they master the topic before we move on to the new topic. So it also takes time to master a certain topic. That's why we ask low-level questions only because we want to catch-up on all topics." [Azah,SRI 1/20390-20903]

\section{Level of Students}

Teachers tend to match their questioning to the students' level or ability as highlighted by Teacher Ana in the following excerpt. To her, it is important that all her students would manage to master some basic questions which would enable them to get a few points in tests.

"Yes, I think the lower level questions are more appropriate for my students. Even the basic questions could not be solved. For example, there are two people who are not very good at division of numbers, so I have to lower my 'level' of teaching so that at least one of these students can have one point or two. [Ana,II/16980-17370]

In addition, high-level oral questions were less frequently posed by teachers who aimed at providing the low-achieving students with the opportunity to participate in mathematics teaching activities. As mentioned, when teachers focus more on high-level oral questions, the class activities are more likely to be dominated by high achieving students and more likely to be answered by the same student.

"we want to give low-achieving students the opportunity to participate in oral questioning activities as well as to prevent high-achieving student to be dominant in answering questions posed by teachers." [Roza,SRI1/21125-215213]

\section{E. Students' Involvement}

Teacher Raha also expressed her opinion that the higher level questions raised during the mathematics teaching would only be dominated by the same students as she mentioned, "If it is a high level question, it will take time 


\section{FACTORS AFFECTING THE IMPLEMENTATION OF LOW-LEVEL ORAL QUESTIONING IN MATHEMATICS TEACHING IN PRIMARY SCHOOL}

and maybe the same student will answer" [Raha,II/1573515823].

In this context 'the same student' refers to the smarter student who dominates the oral questioning activities during the mathematics teaching. Teacher Raha explained further that giving low level questions was intended to provide "low-achieving students the same opportunity to participate" [Raha,II/15882-15989]. Teacher Raha therefore suggested that "If these are high level questions, it is best to be in group form. They can discuss with each other" [Raha,II/14964-15087].

It was also found that lower-level oral questions were used more frequently by teachers who aimed at maintaining students' motivation to stay engaged in the teaching activities. This is explained by Teacher Azah in the interview excerpt below.

"Why do we need to ask the higher level questions when the lower level oral questions are difficult for them to answer? So, in order to increase their enthusiasm and involvement in the teaching of Mathematics, we have lowered the level of questions that fit their abilities." [Azah,SRI 2/10330-10486]

Teacher Azah further argued that it is important for teachers to maintain students "enthusiasm and engagement in their learning as he believes that high-level questions will make students bored because they cannot answer the questions asked and undermine students' ability to learn new topics" [Azah,SRI 1/20905-21152].

\section{F. Level of Teachers' Knowledge}

In addition, the analysis of the interviews conducted also found that teachers were more focused on lower-level oral questions due to their lack of knowledge on oral questioning as well as high order thinking skills (HOTS). This indirectly causes teachers to feel more comfortable using low-level oral questions that focus on the level of remembering and understanding. Teacher Ana said, "Well honestly I have no knowledge and I am not good enough to ask this HOTS question but I will refer to the reference book, the exercise book." [Ana,II/10182-10324].

In addition, this is also supported by Teacher Nadia, who also said the same thing, "As a new teacher I think I still need a lot of knowledge on doing high-level oral questions and need more time to practice."[Nadia,SRI3/10347-10589]. Besides, Teacher Roza noted that:

“...deep knowledge gained by teachers in relation to higher level oral questioning can help teachers implement HOTS-based oral questioning in mathematics teaching, but $\mathrm{i}$ still think I still need the knowledge and skills to improve my ability to practice level questions higher." [Roza,SRI2/14523-15012]

It is clear, therefore, that the level of knowledge of mathematics teachers on how to perform multiple-level oral questions, particularly high-level oral questions, plays a major role in ensuring the effectiveness of oral questioning activities in mathematics teaching.

\section{G. Lack of In-service Training}

In this context, the researchers found that teachers' knowledge was dependent on the training received, especially in-service training in relation to the skills of oral questioning. This is especially needed by the new teachers.

"I think I need more training especially in-service training on oral questioning to increase my knowledge and skills. In addition, I think the authorities need to add training related to oral questioning, especially high-level questioning to new teachers engaged in teaching field." [Ana, SRI 1/2964929940]

This aspect of training is an important aspect in helping mathematics teachers to develop oral questioning skills. It may not have been specifically focused on during their training. In addition, the training provided was also inadequate and teachers needed more exposure and training to make them more confident in performing high-level oral questions.

Thus, mathematics teachers in this study have various reasons for not implementing high-level oral questioning in during their mathematics teaching. All obstacles faced by teachers should be addressed by the school management. Teachers must also be positive in their efforts to address these issues to ensure that students manage to enhance their thinking especially in mathematics learning.

\section{DISCUSSION \& RESULTS}

Factors including time constraint, excessive workload, levels of student achievement, maintaining student engagement, lack of knowledge and inadequate in-service training had contributed to the lack of high-level oral questioning in the teaching of mathematics. The findings of this study need to be interpreted with caution as there are a number of factors that have been discussed by previous researchers on why primary school mathematics teachers prefer to ask lower-level oral questions in their mathematics teaching such as teacher readiness [24] and teaching style [15]. However, this discussion is based on the actual phenomenon and situation of the primary school mathematics teacher being studied.

The findings show that the level of students' proficiency in mathematics in general may contribute to the reasons why teachers are focusing more on lower-level oral questions in their mathematics teaching. This is supported by [3] who found that low students' ability in mathematics subjects made it difficult for teachers to practice high level oral questions. It is apparent that students who are still unable to master the mathematical concepts would face difficulty to establish connection between mathematical ideas if the classroom teaching focuses heavily on higher level questions. Based on the observations, it was found that lower-level questions were more frequently directed to weaker students instead of the high achievers. It can be seen that teachers are providing the opportunity to low-achieving students to be actively engaged in teaching activities. This is in line with the findings of [9] in which she stated that if high-level questions are asked openly, only clever students will dominate answering the questions asked. Therefore, teachers should be wise in asking questions based on the students' cognitive level so that the opportunity for students 
to answer the questions posed by the teacher is even greater.

In addition, the findings also show that factors in maintaining student engagement during the teaching process are the reason why math teachers focus more on lower-level oral questions. In this context, asking high-level oral questions will result in less response from the students and causing the learning environment to be passive and less enjoyable. This is because students find it difficult to understand the high-level questions posed to them, resulting in less response from students. This is supported by the study of [19] who stated that high-level questions asked by teachers are difficult for students to answer because they do not understand the high-level questions asked. As a consequence, the lack of response from students will indirectly cause anxiety to the teachers and may result in teachers preferring to perform low-level oral questioning activities in order to obtain response and engagement from students.

In the context of the development of the education sector in Malaysia, complaints have been everywhere, including social media, which has also raised the issue of teacher workload. Therefore, it is expected that the participants in this study also raise on the issue of workload as a factor that prevents them from performing high-level oral questioning in their teaching. This finding is in line with the study of [20] who also found that heavy workload indirectly interfered with the quality of teaching. It may also lead to depression and resulting in teachers' inability to focus on the teaching. This is a serious matter that needs to be addressed as it may interfere with the emotions and teaching performance especially for new teachers who are still trying to adapt with the demands of the teaching profession. It has been pointed out in [21] study that new teachers often suffer from emotional stress and are unable to focus on the teaching activities that they are carrying out due to the heavy workload. Therefore, teachers should be wise in handling activities outside the classroom especially for new teachers who are adapting to the actual situation of the teacher's task in order to plan for better teaching activities that involve higher-level oral questioning.

The findings also show that heavy workload indirectly disrupts teaching time and sometimes it has to be used to complete various tasks and has to leave the classroom to complete the assignment. This reduces the time allotted for mathematics teaching, making it more difficult for teachers to practice high-level oral questions in their teaching. Implementation of higher level oral questioning activities require more time for discussion because the questions are open-ended. Therefore, teachers prefer to conduct low-level oral questioning to ensure that the teaching and learning process is completed in the allocated time.

In addition, constraint of time may also restrict the teachers from making good teaching plan which includes the oral questions to be posed during class time. This aspect of planning is very important in the practice of oral questioning and can help teachers to practice oral questioning more effectively [22]. The findings of this study also support the fact that teachers do not plan for oral questions to be used in their mathematics teaching and indirectly, this led to a more spontaneous oral questioning which only raises low-level oral questions [27]. The implementation of effective oral questioning should be well planned so that it can actually improve students' understanding of mathematics as well as meeting the needs of students with varying degrees of ability. Designing oral questions that will be asked to students is emphasized in the [23] as a guide in implementing effective oral questioning in the teaching process. In this context, teachers should plan for oral questioning activities that will be used to ensure appropriate and effective oral questioning activities.

In addition, the large number of topics to be covered in a school year may cause teachers to hurry in finishing the syllabus and thus make the teaching and learning process more procedural and algorithmic, while at the same time reducing oral questioning activities during the mathematics teaching. As a result of trying to finish off all the topics, mathematics teaching will be more linear and less focused on stimulating student thinking. This is also in line with the study [24] which found that teachers are less likely to engage in activities that promote HOTS and tend to pursue the syllabus. This indirectly causes teachers to fail in stimulating student thinking and to cause less student involvement in the teaching and learning process [19].

In addition, the findings of this study also highlights on the inadequacy of teachers' knowledge in implementing. This may cause teachers to focus only on lower-level oral questions rather than higher-level oral questions. This may, in turn, cause teachers to feel that they have applied the question in implementing HOTS but in reality, it is only low-level thinking skills.

The participants in this study also felt that higher level oral questions are only appropriate for the smart and highachieving students. This is supported by [9] who also found that some math teachers still think that HOTS is only suitable for high-achieving students. In this context, teachers may perceive that poor students have low thinking ability and are unable to complete tasks that require HOTS. However, this is actually a misconception because teachers should encourage students at all levels to participate in HOTS-related assignments. This view that the teaching and learning opportunities for HOTS development are for all students and not limited to high-achieving students only, needs to be corrected. It is the duty of the teacher to design mathematical instruction wisely to ensure that HOTS can be implemented for students of all levels especially through oral questioning activity.

In-service training is one of the requirements for teachers to develop knowledge and skills in planning and implementing mathematics teaching more effectively [25]. The reason given by participants that they lack exposure to conduct oral questioning at higher levels should be followed up by giving every teacher the opportunity to attend inservice course because the demands of education changes with the current needs of the individual and the society. In [26] posited that the implementation of oral questioning at higher levels can only be effectively implemented if teachers have sufficient training and in-depth knowledge of how to perform oral questioning in accordance with

Published By: 


\section{FACTORS AFFECTING THE IMPLEMENTATION OF LOW-LEVEL ORAL QUESTIONING IN MATHEMATICS TEACHING IN PRIMARY SCHOOL}

established guidelines. In [5] also pointed out that aspects of teacher training in oral questioning are still at a low level. In addition, the possibility of ineffective training models and representative systems attending non-systematic courses or training may also cause teachers to become less skilled at implementing oral presentation on HOTS [25]. As such, education departments including the school administration need to re-examine this issue and provide support by increasing the holistic training of mathematics teaching including in the area of effective oral questions and ensuring that the training modules truly meet current needs of teachers to understand and apply oral questioning at a higher level.

\section{CONCLUSION}

In conclusion, all of the reasons discussed above should be carefully researched to find the best solution so that the mathematical teaching process implemented can actually improve students' thinking especially through higher level oral questioning activities. This is important to ensure that the government's ambition to enhance HOTS and Malaysia's position in global assessment of TIMSS and PISA will be achieved.

\section{REFERENCES}

1. J. Way, "Using questioning to stimulate mathematical thinking," Aust. Prim. Math. Classr., vol. 13, no. 3, pp. 22-27, 2008.

2. A. Ö. Çelik and E. B. Güzel, "A mathematics teacher's questioning approaches for revealing students' thinking during lesson study," Turkish J. Comput. Math. Educ., vol. 7, no. 2, pp. 365-392, 2016.

3. M. Shahrill and D. J. Clarke, "Brunei teachers' perspectives on questioning: Investigating the opportunities to "talk" in mathematics lessons," International Education Studies, vol. 7, no. 7, pp. 1-8, 2014.

4. Bahagian Pembangunan Kurikulum, Kemahiran Berfikir Aras Tinggi: Aplikasi di Sekolah. Putrajaya: Kementerian Pendidikan Malaysia, 2014.

5. S. Abd. Mutalib and J. Ahmad, "Kepelbagaian aras soalan lisan dalam pentaksiran formatif bagi subjek Geografi,” J. Teknol., vol. 59, no. 1, pp. 103-108, 2012.

6. I. Weiland, R. Hudson, and J. Amador, "Preservice formative assessment interviews: The development of competent questioning," Int. J. Sci. Math. Educ., vol. 12, no. 2, pp. 329-352, 2014.

7. L. R. Larson and M. D. Lovelace, "Evaluating the efficacy of questioning strategies in lecture-based classroom environments: Are we asking the right questions?0," J. Excell. Coll. Teach., vol. 24, no. 1, pp. 105-122, 2013.

8. S. R. Hassan, R. Rosli, and E. Zakaria, "The use of iThink Map and questioning to promote higher-order thinking skills in mathematics," Creat. Educ., vol. 7, no. 7, pp. 1069-1078, 2016.

9. A. Zohar and Y. J. Dori, "Higher order thinking skills and low-achieving students," J. Learn. Sci., vol. 12, no. 2, pp. 145-181, 2003.

10. D. Desli and E. Galanopoulou, "Questioning in primary school mathematics: An analysis of questions teachers ask in mathematics lessons," 3rd International Symposium on New Issues on Teacher Education, 2017, pp. 97-105.

11. L. W. Anderson and D. R. Krathwohl, A taxonomy for learning, teaching, and assessing: A revision of Bloom's taxonomy of educational objectives. London: Longman, 2001.

12. S. Kaya, Z. Kablan, and D. Rice, "Examining question type and the timing of IRE pattern in elementary science classrooms,” Int. J. Hum. Sci. / Uluslararası İnsan Bilim. Derg., vol. 11, no. 1, pp. 621-641, 2014.

13. O. Belcher Jr., Effectiveness of a formative assessment initiative on student achievement in eighth grade math. PhD thesis, Clinton: Missisippi College, 2016.

14. P. Albergaria-Almeida, "Questioning patterns and teaching strategies in secondary education," Procedia Soc. Behav. Sci., vol. 2, no. 2, pp. 751-756, 2010.

15. T. Z. Tengku Zawawi, M. Ramlee, and H. Abdul Razak, "Pengetahuan pedagogi isi kandungan guru matematik bagi tajuk pecahan: Kajian kes di sekolah rendah," J. Pendidik. Malaysia, vol. 34, no. 1, pp. 131-153, 2009.

16. M. B. Miles, A. M. Huberman, and J. Saldana, Qualitative Data Analysis. California: Sage Publications, 2013.

17. R. C. Bogdan and S. K. Biklen, Qualitative Research for Education: An Education to Theories and Methods. London: Pearson Education, 2007.

18. J. W. Creswell, Research Design: Qualitative, Quantitative, and Mixed Methods Approaches. California: Sage Publications, 2014.

19. N. Kassim and E. Zakaria, "Integrasi kemahiran berfikir aras tinggi dalam pengajaran dan pembelajaran matematik: Analisis keperluan guru," J. Pendidik. Mat., vol. 3, no. 1, pp. 1-12, 2013.

20. N. Abdullah, N. M. Noh, R. Mansor, M. Hashim, A. Talib, and K. T. Wong, "Penilaian pelaksanaan Pentaksiran Berasaskan Sekolah (PBS) dalam kalangan guru sains," Jurnal Pendidikan Sains dan Matematik Malaysia, vol. 5, no. 1, pp. 89-102, 2015.

21. S. Sezer, 'Novice teachers' opinions on students' disruptive behaviours: A case study," Eurasian J. Educ. Res., vol. 67, pp. 161-182, 2017.

22. D. Hayes, Planning, Teaching and Class Management in Primary Schools. Abingdon: Routledge, 2013.

23. Bahagian Pembangunan Kurikulum, Bahan Sumber Peningkatan Kemahiran Berfikir Aras Tinggi Matematik: Panduan Penggunaan Soalan Programme For International Student Assessment (PISA). Putrajaya: Kementerian Pendidikan Malaysia, 2013.

24. Z. A. Rashid, Tahap kesediaan guru dalam aspek pengetahuan dan keperluan latihan berfokuskan aplikasi KBAT. Master thesis, Johor: Universiti Tun Hussein Onn Malaysia, 2016.

25. K. D. Rohaya Talib, M. Z. Kamsah, and H. A. Naim, "Pedagogi dan pentaksiran: Kongruen?," Seminar Kebangsaan Majlis Dekan-Dekan Pendidikan IPTA 2014, 2014.

26. M. A. Buhagiar, "The classroom assessment cycle within the alternative assessment paradigm: Exploring the role of the teacher," J. Maltese Educ. Res., vol. 4, no. 2, pp. 17-36, 2006.

27. M. S. Mahmud, A. S. M. Yunus, A. F. M. Ayub, and T Sulaiman, "Case study of the level of oral questioning used by teachers in formative assessment during the mathematics teaching process in primary school," Reli. Rev. Ciencias Soc. y Humanidades., vol. 4, no. 18, pp. 515-522, 2019 


\section{AUTHORS PROFILE}

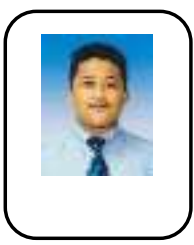

Muhammad Sofwan Mahmud is a lecturer in mathematics education at the National University of Malaysia. He holds a bachelor's and master's degree in mathematics education. $\mathrm{He}$ is currently pursuing a doctorate in mathematics education at Universiti Putra Malaysia. To date he has published several publications that focus on pedagogy and teaching mathematics. Accordingly, he has won several publishing awards and has won several teaching innovation competitions at various levels.

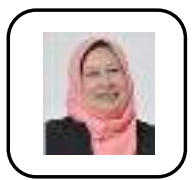

Dr Aida Suraya Md Yunus is a Professor of Mathematics Education and currently, she is the Dean of the Faculty of Educational Studies of Universiti Putra Malaysia (UPM). Prior to the appointment as dean, she was the Director of the Centre for Academic Development of UPM and Chairman for the Council for Directors/Heads of Teaching Learning Centres of Public Universities. Dr Aida Suraya is an associate researcher with the lnstitute of Mathematical Research and fellow of the National Higher Education Research lnstitute. She has collaborated with the Research lnstitute of Higher Education (RIHE) of Hiroshima University on a project on Academic Profession in Asia (APA). She did two projects with the Education Research Institutes Networks (ERl-Net) of UNESCO Bangkok; i.e. (i) Transition from school to higher education (ii) Promotion of teaching personnel in higher education. Currently, she leads a project with the lnnovative Research Universities of Australia to develop Criteria and Standards for Effective Teaching in Higher Education. She is recognized as a teaching and learning expert by the Ministry of Higher Education Malaysia. She is part of several task force committees including the Deputy Chairman for the Developmen of Criteria for Award of HICOE (Higher Institution Centre of Excellence) for Teaching and Learning, task force for realizing Shift \#9 of the Malaysian Education Blueprint on globalized online learning, and the National Committee Member for MOOC Development. The Malaysian Qualifications Agency (MOA) has engaged her expertise in developing the Guideline for Credit Transfer for MOOC and Guideline for Good Practices: Assessment of Students. She is also a Master Trainer of the Malaysian Higher Education Leadership Academy (AKEPT) for teaching and learning in higher education. She is also one of the writers for the Commonwealth document on Quality Standards in Education. She has done numerous training programmes on outcome-based education, assessment of learning outcomes, curriculum development and teaching and learning in higher education for several higher learning institutions (MOA, AKEPT, UPM, UPNM, USIM, UNIMAS, UTEM, UNIMAP, UMS, and polytechnics).

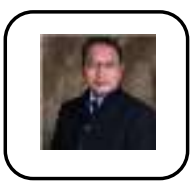

Ahmad Fauzi Mohd Ayub career as an educator started when he was appointed as a Matriculation teacher at Universiti Putra Malaysia upon completion of his Diploma of Education in 1994. However, in 1998 , following a policy change by the Ministry of Education, the Matriculation Centre in Universiti Putra Malaysia was closed. This marked a new phase in Ahmad Fauzi's career. He was transferred to the Faculty of Educational Studies in 2000. During that time, he pursued a Master of Information Technology degree at Universiti Teknologi MARA In compliance with the university requirement that lecturers needed to have the highest academic qualification, Ahmad Fauzi Mohd Ayub went on to pursue his studies at $\mathrm{PhD}$ level in 2003 at Universiti Kebangsaan Malaysia. As a post-graduate student, he developed an educational Multimedia Courseware for teaching and learning mathematics Calculus for diploma level. Upon completion of his studies, Dr. Ahmad Fauzi Mohd Ayub returned to Universiti Putra Malaysia in 2008 and was appointed senior lecturer. In July 2012, he applied for sabbatical leave to focus on his research and writing. He was appointed as Associate Professor in 1st February 2014.As a principal lecturer, Dr. Ahmad Fauzi Mohd Ayub taught 32 courses mainly related to information and communication technology in education, leading to the Bachelor of Education (Information Technology) degree. The courses he conducted involved both theoretical concepts and practical laboratory work. He also assisted students in their development of multimedia tools for educational use. Besides that, Dr. Ahmad Fauzi also taught other subjects such as testing and measurement courses and research methods. His courses at postgraduate level included Computer in Teaching and Learning, and Multimedia and Communication Technology, covering both instructional, as well as educational statistics courses. As a lecturer, Dr. Ahmad Fauzi Mohd Ayub received excellent service awards in 1997 , 1999, 2002, 2003, 2008, 2009, 2010 and 2011. He was named Excellent Young Researcher for 2010 and 2011 by the Institute for Mathematical
Research. In 2010 he also received the Excellent Researcher award. Dr Ahmad Fauzi has also been an active participant in science exhibitions, mostly at university level. He had participated in Research and Innovation Exhibitions in UPM since 2007, winning 16 medals, of which two were gold, 11 silver and two bronze. In 2011, he won a bronze medal at the Malaysian Technology Expo. Recently, he has won 1 silver and Bronze medal from Malaysian Technology Expo 2014

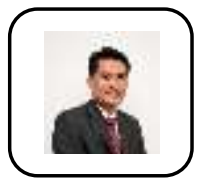

Dr. Tajularipin Sulaiman received his early education in Muar, Johor and continued his secondry education at the Sekolah Teknik Malacca. He continued his studies at the Centre for Foundation Studies in Science, Universiti Malaya in 1998. He obtained the Bachelor of Science with Education Degree in 1994 and Master of Education in 1998 from the University Malaya. He holds a doctoral degree in education from University Putra Malaysia. His area of specialization is in pedagogy, science education, and cognitive development. He has involved in courses in science education, thinking skills and primary education. He research interest is in the field of pedagogy and primary education especially in primary science. He has also presented papers in national and internationa conferences. 